\title{
EFETIVITAS HUKUM SISTEM E-PROCUREMENT DALAM PENGADAAN BARANG DAN JASA SECARA ELEKTRONIK
}

\author{
Candra Nur Hidayat \\ Universitas Pamulang \\ hidayat.candra2493@gmail.com
}

\begin{abstract}
In organizing the life of the state, the government is always required to advance public welfare. Because there is no country that does not have a purpose and a variety of goals for that country. To carry out this obligation, the government has an obligation to provide the needs of the people in various forms in the form of goods, services and infrastructure development. on the other hand, the government also needs goods and services in carrying out government, for that it needs goods and services procurement. Procurement of goods and services is essentially an effort of the user to obtain or realize the goods and services he wants by using certain methods and processes in order to reach an agreement on price, time and other agreements. So that the nature and essence of the procurement of goods and services can be carried out as well as possible, then both parties, namely the user and provider must always be guided by the philosophy of procurement of goods and services, subject to the ethics and norms of procurement of goods and services that apply, following the principles principles, methods and processes for procuring raw goods and services. In a good procurement system of goods and services is a system of procurement of goods and services that is able to apply the principles of good governance and clean (Good Governance and Clean Governance), encourage efficiency and effectiveness of public spending, and structuring the behavior of the three pillars (government, private and community).
\end{abstract}

Keywords: e-procurement, legal effectiveness, regulatory agencies.

\begin{abstract}
Dalam penyelenggaraan kehidupan bernegara, pemerintah senantiasa dituntut untuk memajukan kesejateraan umum. Karena tidak ada suatu Negara yang tidak mempunyai tujuan dan beranekaragam tujuan Negara itu. Untuk mengemban kewajiban ini, pemerintah mempunyai kewajiban menyediakan kebutuhan rakyat dalam berbagai bentuk baik berupa barang, jasa maupun pembangunan infrastruktur. di sisi lain, pemerintah juga memerlukan barang dan jasa itu dalam melaksanakan pemerintahan, untuk itu perlu pengadaan barang dan jasa. Pengadaan barang dan jasa pada hakikatnya merupakan upaya pihak pengguna untuk mendapatkan atau mewujudkan barang dan jasa yang diinginkannya dengan menggunkan metode dan proses tertentu agar dicapai kesepakatan harga, waktu dan kesepakatan lainnya. Agar hakikat dan esensi pengadaan barang dan jasa tersebut dapat dilaksanakan dengan sebaik-baiknya, maka kedua belah pihak yaitu pihak pengguna dan penyedia haruslah selalu berpatokan pada filosofi pengadaan barang dan jasa, tunduk kepada etika dan norma pengadaan barang dan jasa yang berlaku, mengikuti prinsip-prinsip, metode dan proses pengadaan barang dan jasa yang baku. Dalam sistem pengadaan barang dan jasa yang baik adalah sistem pengadaan barang dan jasa yang mampu menerapkan prinsip-prinsip tata pemerintahan yang baik dan bersih (Good Governance and Clean Governance), mendorong efisiensi dan efektivitas belanja publik, serta penataan prilaku tiga pilar (pemerintah, swasta dan masyarakat).
\end{abstract}

Kata kunci: $e$-procurement, efektivitas hukum, lembaga pengawas. 


\section{PENDAHULUAN}

Dalam perkembangan teknologi informatika telah membuat dunia tanpa batas. Kemampuannya yang menjangkau seluruh pelosok dunia yang terhubung melalui sebuah jaringan online dapat membuat para pengguna terhubung satu sama lain. Apalagi dalam penyelenggaraan kehidupan bernegara, pemerintah senantiasa dituntut untuk memajukan kesejateraan umum. Internet yang berwujud sebagai halaman situs dapat sangat mudah diakses oleh semua orang, banyak memberikan informasi yang berguna sesuai dengan kepentingannya (Sakti, 2014 : 4). Maka itu untuk memanfaatkan teknologi pada era ini pemerintah membuat system yang dapat mempermudah para pengguna barang dan jasa dalam pekerjaannya dengan cara mengubah system yang tadinya konvensional menjadi system secara elektronik (E Procurement), di sisi lain, pemerintah juga memerlukan barang dan jasa itu dalam melaksanakan pemerintahan, untuk itu perlu pengadaan barang dan jasa yang lebih efektif dan efisien.

Pengadaan barang dan jasa

dimulai dari adanya transaksi pembelian/penjualan barang di pasar secara langsung (tunai), kemudian berkembang ke arah pembelian berjangka waktu pembayaran, dengan membuat dokumen pertanggungjawaban (pembeli dan penjual), dan pada akhirnya melalui pengadaan, melalui proses pelelangan. Dalam prosesnya, pengadaan barang dan jasa melibatkan beberapa pihak terkait sehingga perlu ada etika, norma dan prinsip pengadaan barang dan jasa untuk dapat mengatur atau yang dijadikan dasar penetapan kebijakan pengadaan barang dan jasa.
Pengadaan barang/Jasa oleh pemerintah melibatkan uang yang sangat besar. Itulah sebabnya dikatakan pemerintah merupakan pembeli yang terbesar (the largest buyer) di suatu Negara. Dalam kaitan ini pemerintah mempunyai tanggung jawab agar kebijakan dalam bidang pengadaan maupun mendukung tujuan ekonomi dan menetapkan instrument-instrumen dalam rangka mencapai tujuan tersebut (Christine, $2011: 363$ ).

Dalam sistem pengadaan barang dan jasa yang baik adalah sistem pengadaan barang dan jasa yang mampu menerapkan prinsipprinsip tata pemerintahan yang baik dan bersih (Good Governance and Clean Governance), mendorong efisiensi dan efektivitas belanja publik, serta penataan prilaku tiga pilar (pemerintah, swasta dan masyarakat) dalam penyelengaraan tata pemerintahan yang baik dan bersih. Sebagaimana tercantum dalam Undang-undang Nomor 14 Tahun 2008 tentang keterbukaan informasi publik, dimana salah satu tujuan dari keterbukaan informasi publik adalah untuk mewujudkan penyelenggaraan yang baik dan bersih, yaitu yang transparan, efektif, efisien, akuntabel serta dapat dipertanggungjawabkan.

Berangkat dari hal di atas, hadirlah electronic procurement yang selanjutnya disingkat sebagai eprocurement sebagai suatu sistem lelang dalam pengadaan barang dan jasa oleh pemerintah dengan menggunakan sarana teknologi, informasi dan komunikasi berbasis internet. Dengan e-procurement, proses lelang dapat berlangsung secara efektif, efisien, terbuka, bersaing, transparan, adil/tidak diskriminatif, dan akuntabel sehingga 
diharapkan dapat mencerminkan keterbukaan/transparansi dan juga meminimalisasi praktik curang dalam lelang pengadaan barang dan jasa yang berakibat merugikan keuangan negara.

E-Procurement mulai diterapkan sejak tahun 2007 dengan berdirinya Lembaga Kebijakan Pengadaan Barang/Jasa Pemerintah ${ }^{5}$. E- Procurement adalah proses pengadaan barang/jasa pemerintah yang pelaksanaannya dilakukan secara elektronik yang berbasis web/internet dengan memanfaatkan fasilitas teknologi komunikasi dan informasi yag meliputi pelelangan umum secara elektronik. Pengadaan secara elektronik sejak disahkannya UndangUndang Nomor 11 Tahun 2008 tentang Informasi dan Transaksi Elektronik telah diberi ruang bergerak yang luas secara hukum. $E$ procurement sebagai suatu sistem informasi merupakan suatu sinergi antara data, mesin pengolah data (yang biasanya meliputi komputer, program aplikasi, dan jaringan) dan manusia untuk menghasilkan informasi.

Pelaksanaan e-procurement termasuk ke dalam salah satu program nasional untuk mewujudkan pemerintahan yang bersih dan bebas korupsi, kolusi dan nepotisme. Dimana nantinya melalui program tersebut seluruh instansi pemerintah baik pusat maupun daerah harus menerapkan e-procurement dalam pengadaan barang/jasa. $E$ procurement menawarkan kesempatan seluas-luasnya untuk perbaikan dalam biaya dan produktivitas. Oleh karenanya $e$ procurement merupakan salah satu cara yang paling efektif untuk menyempurnakan manajemen, baik langsung maupun tidak langsung, dalam pencarian sumber pembelian. Walhasil, e-procurement akan meningkatkan kunci keberhasilan dalam peningkatan daya saing di masa datang.

Agar hakikat atau esensi pengadaan barang/jasa tersebut dapat dilaksanakan sebaik-baiknya, maka kedua belah pihak yaitu pihak pengguna dan penyedia harus selalu berpatokan pada filosofi pengadaan barang/jasa, tunduk kepada etika dan norma pengadaan barang/jasa yang baku. Filosofi pengadaan barang/jasa adalah upaya untuk mendapatkan barang/jasa yang dilakukan atas dasar pemikiran yang logis dan sistematis (The system of thought), mengikuti norma dan etika yang berlaku, berdasarkan metode dan proses pengadaan yang baku (sutedi, $2010: 3)$.

\section{METODE PENELITIAN}

Dalam penelitian ini penulis lakukan berdasarkan metode penelitian dimana Jenis Penelitian ini dilakukan secara yuridis empiris, yaitu metode penelitian yang dilakukan dengan cara mempersiapkan masalah dan konsepkonsepnya (Soekanto, 1986 : 5). Penelitian ini mengacu pada norma hukum yang terdapat diperaturan perundang-undangan. Metode penelitian yang digunakan penulis dalam penelitian ini adalah yuridis sosiologis. Dalam yuridis sosiologi, hukum sebagai law in action. Penelitian ini dilakukan dengan mencari data-data dan Teknik pengumpulan data dilakukan melalui penelahaan data yang sudah diperoleh dari perundangundangan, buku-buku teks, hasil majalah artikel, dan mengunjungi situs internet serta observasi yang berhubungan dengan masalah. 


\section{PERMASALAHAN}

Sehingga timbul permasalahan yang harus diselesaikan yakni Bagaimana efektivitas hukum system eprocurement dalam pengadaan barang dan jasa pemerintah secara elektronik?

\section{PEMBAHASAN}

\section{Efektivitas hukum pengadaan barang dan jasa pemerintah secara elektronik procurement) \\ (electronic}

Sampai dengan saat ini, metode pengadaan barang dan jasa yang dianggap lebih baik karena pelaksanaannya lebih efektif, efisien dan transparan adalah dengan metode pengadaan barang dan jasa secara elektronik atau e-procurement. Dengan e-procurement, proses lelang dapat berlangsung secara efektif,efisien, terbuka, bersaing, transparan, adil/tidak diskriminatif dan akuntabel sehingga diharapkan dapat mencerminkan keterbukaan/transparansi dan juga meminimalisasi praktek curang/Korupsi Kolusi Nepotisme dalam lelang pengadaan barang/jasa yang mengakibatkan kerugian keuangan negara.

Pada penelitian ini, penulis ingin mengetahui sampai sejauh mana efektivitas hukum pengadaan barang/jasa secara elektronik (eprocurement) dilihat dari efektivitas perundang-undangannya. Efektifnya suatu perundang- undangan dapat dilihat dari berbagai faktor yaitu (Ali, 2009 : 378-379):

a. Pengetahuan tentang substansi (isi) perundang-undangan

b. Cara-cara untuk memperoleh pengetahuan tersebut

c. Institusi yang terkait dengan ruang lingkup perundangundangan di dalam masyarakatnya d. Bagaimana proses lahirnya suatu perundang-undangan yang tidak boleh dilahirkan secara tergesa-gesa untuk kepentingan instan (sesaat) yang diistilahkan sebagai sweep legislation (undangundang sapu), yang memiliki kualitas buruk dan tidak sesuai dengan kebutuhan masyarakatnya.

Efektivitas perundangundangan dapat dilihat dari 2 (dua) prespektif yaitu:

a. Prespektif organisatoris, yaitu prespektif yang memandang perundang- undangan sebagai "institusi" yang ditinjau dari ciri-cirinya.

b. Prespektif individu atau ketaatan, yaitu lebih banyak berfokus pada segi individu atau pribadi, di mana pergaulan hidupnya diatur oleh perundang-undangan.

Terkait tentang pengadaan barang/jasa pemerintah adalah Peraturan Presiden Nomor 16 Tahun 2018. Di Perpres No 16 Tahun 2018 ini, pengadaan barang/jasa diatur secara khusus pada pasal 104 sampai dengan pasal 112. Pengaturan tentang $e$ procurement dianggap mendesak karena didasarkan pada fenomena yang ada dalam masyarakat pada saat sekarang ini dimana banyaknya proses pengadaan barang dan jasa yang terindikasi adanaya praktek korupsi, kolusi dan nepotisme.

Selain menghemat anggaran pemerintah, manfaat lainnya dari $e$ - procurement bagi instansi/ lembaga yang menerapkan $e$ procurement adalah dapat membuat proses interaksi antara pengguna dan penyedia jasa, serta masyarakat berjalan lebih mudah serta mempercepat proses 
pengadaan. Tidak kalah penting, penerapan e-procurement secara otomatis meningkatkan sistem kontrol terhadap berbagai penyimpangan dan pelanggaran aturan. Perubahan dalam proses ini ditempuh dengan memanfaatkan kemajuan teknologi informasi sebagai media interaksi antara kedua belah pihak.

Meskipun dalam Perpres

Nomor 16 Tahun 2018 Tentang Pengadaan Barang/Jasa telah diatur mengenai sanksi bagi setiap pelanggaran dalam proses pengadaan barang dan jasa pemerintah tetapi sanksi yang ada masih bersifat umum dan tidak tegas dalam pemberian hukumannya. Hukuman yang ada hanya berupa tuntutan ganti rugi dan pemasukan dalam daftar hitam (black list) padahal kalau dicermati pelanggaran yang ada tidak hanya pelanggaran administratif dan pelanggaran perdata saja tetapi juga terdapat pelanggaran pidana.

Di samping itu, produk hukum dari pengaturan pengadaan barang dan jasa yang ada sekarang ini masih berupa Peraturan Presiden yang masih dapat berubah-ubah jika Presidennya diganti. Untuk itu, perlu adanya peraturan yang lebih tinggi, bersifat konsisten dan memiliki sanksi hukum yang tegas untuk menekan adanya penyelewengan dalam pengadaan barang dan jasa pemerintah. Aturan atau produk hukum itu adalah undang-undang.

\section{Keberadaan undang-} undang yang mengatur pengadaan barang dan jasa, khususnya yang mengatur tentang pengadaan barang dan jasa secara elektronik (eprocurement) diharapkan dapat menekan kebocoran anggaran dalam pengadaan barang dan jasa. Hal ini dikarenakan undang- undang mengatur mulai dari perencanaan, pengadaan, hingga pelaksanaan proyek. Dengan demikian, undang-undang tentang pengadaan barang dan jasa secara elektronik (e-procurement) tersebut merupakan upaya mencegah kemungkinan terjadinya kebocoran dalam pengadaan barang dan jasa. Undang-undang tersebut nantinya juga perlu mencantumkan hak pengawasan dan hak paksa yang mengacu pada undang-undang anti korupsi serta tidak lupa juga sanksi yang tegas terhadap pelaku pelanggaran dalam proses pengadaan barang dan jasa da harus sesuai dengan undang-undang yang lain.

Dengan sistem e-procurement ini peluang kontak langsung antara penyedia barang dan jasa dengan panitia pengadaan semakin kecil sehingga meminimalisir terjadinya kolusi sebagaimana yang sering terjadi di dalam pengadaan barang dan jasa secara konvensional. Dengan demikian aspek efisien dan efektivitas telah dapat dijalankan dengan baik.

Pasal $1233 B W$ menyebutkan:" tiap-tiap perikatan dilahirkan baik karena persetujuan baik karena undangundang”. bahwa perikatan itu timbul maka ada konsekwensi hukum bahwa adanya dua pihak yang masing-masing pihak karena perikatan tersebut mempunyai hak dan pihak lain mempunyai kewajiban yang mana harus dilaksanakan sesuai dengan perikatan yang telah disepakati. Pasal $1233 B W$ tersebut diatas dipertegas dengan pasal $1234 B W$ yang menyatakan:" Tiap-tiap perikatan adalah untuk memberikan sesuatu, untuk berbuat sesuatu atau untuk tidak berbuat sesuatu." Sehingga perikatan menimbulkan hak dan kewajiban di lapangan hukum kekayaan, para pihak dengan sukarela membuat perjanjian yang mana dengan perjanjian tersebut mengikatkan diri satu sama 
yang lain untuk berbuat sesuatu atau tidak berbuat sesuatu dalam memenuhi hak dan kewajibannya.

Sedangkan yang dimaksud dengan lapangan kekayaan adalah perjanjian yang berkaitan dengan perjanjian yang berhubungan dengan harta kekayaan seseorang, seperti pasal $1131 B W$ yang menyatakan :" Segala kebendaan milik debitor, baik yang bergerak maupun yang tidak bergerak, baik yang sudah ada maupun yang baru akan ada dikemudian hari, menjadi tanggungan untuk segala perikatannya seseorang." Dengan demikian sangatlah jelas bahwa dalam ilmu hukum diatur secara tegas bangunan hukum atau konstruksi hukum beserta akibat hukumnya sehingga kegiatan yang mengharuskan para pihak untuk membuat perikatan harus dilandasi dasar kepentingan yang dilindungi oleh undang-undang.

\section{Peran lembaga pengawas dalam pengadaan barang dan jasa}

Pengawasan dapat diartikan sebagai suatu kegiatan pengamatan dan penilaian secara berkesinambungan terhadap suatu objek kegiatan dengan menggunakan metode, alat, dan aturan tertentu untuk menjamin kesesuaian pelaksanaannya dengan rencana dan kebijakan yang telah ditetapkan. Pengawasan barang dan jasa adalah pengawasan yang dilakukan terhadap pelaksanaan pengadaan barang dan jasa apakah telah sesuai dengan rencana, prinsip dasar pengadaan, prosedur, dan aturan yang berlaku. Hakikat pengawasan adalah untuk mencegah sedini mungkin terjadinya penyimpangan, pemborosan, dan kegagalan, serta agar pengadaan dapat berjalan dengan efisien, efektif, hemat dan tertib. Pengawasan pengadaan barang dan jasa di instansi pemerintah merupakan tanggung jawab setiap pimpinan dalam instansi pemerintah yang terkait dengan pengadaan.

Pengawasan dalam pengadaan barang dan jasa wajib dilakukan instansi pemerintah sebagai upaya mewujudkan keadilan, transparansi, dan akuntabilitas dalam rangka penyelenggaraan pemerintahan yang baik (good governance).

Sebagaimana diatur dengan ketentuan dalam Peratura Presiden Nomor 16 Tahun 2018 tentang pengadaan barang dan jasa, pengawasan dan pemeriksaan atas pengadaan barang dan jasa dimaksudkan untuk:

a. Meningkatkan kinerja aparatur pemerintah, mewujudkan aparatur yang profesional, bersih, dan bertanggung jawab

b. Memberantas penyalahgunaan wewenang dan praktek Korupsi, kolusi dan nepotisme.

c. Menegakkan peraturan yang berlaku dan mengamankan keuangan negara.

Untuk mendukung prinsip-prinsip pengadaan barang dan jasa pemerintah yang sesuai dengan ketentuan, maka dalam proses pengadaan barang dan jasa, ada beberapa pihak yang terlibat dalam fungsi pengawasan tersebut, yaitu:

1. Pimpinan dari Instansi pemerintah yang bersangkutan

Fungsi pengawasan yang dilakukan oleh pimpinan instansi/ lembaga ini bersifat pengawasan preventif dan pengawasan represif yaitu dengan cara:

a. Menetapkan kebijakan dan petunjuk teknis (juknis) pelaksanaan pengadaan 
barang dan jasa

b. Menciptakan pengendalian sistem dalam rangka pengadaan barang dan jasa

c. Menciptakan pemantauan sistem terhadap pelaksanaan pengadaan barang dan jasa

d. Mewajibkan kepada pengguna barang/jasa dan panitia/pejabat pengadaan untuk mendokumentasikan setiap proses pengadaan barang dan jasa, serta menyimpannya sebagai alat pertanggungjawaban.

2. Pengguna Barang dan jasa

Sebagai pihak yang berkepentingan terhadap pengadaan barang dan jasa dalam penyelenggaraan pemerintahan sesuai dengan tugas pokok dan fungsinya, maka pengguna barang dan jasa dapat melakukan pengawasan preventif yaitu dengan cara:

a. Menyusun rencana kerja yang menggambarkan kegiatan yang harus dilaksanakan, bentuk hubungan kerja dan sasaran yang harus dicapai

b. Menyusun prosedur pelaksanaan kegiatan secara tertulis agar bisa dimengerti dan dilaksanakan, terutama yang terkait dengan pengadaan barang/jasa

c. Melaksanakan pencatatan dan pelaporan atas hasil kegiatan pengadaan barang dan jasa

d. Menyimpan dan memelihara catatan, laporan serta dokumen lain yang berhubungan dengan pengadaan barang dan jasa

e. Melakukan pengawasan dan pemeriksaan atas pelaksanaan pekerjaan yang sudah dan sedang dilaksanakan penyedia barang dan jasa, bila diperlukan dapat memerintahkan pihak ketiga untuk melakukannya, seperti kantor konsultan, kantor akuntan, dan BPKP.

\section{Unit Pengawasan Intern}

Unit pengawasan intern adalah suatu unit yang berada dalam suatu instansi dan independen terhadap unit lain, serta bertanggung jawab langsung terhadap pimpinan instansinya. Sesuai dengan fungsinya, dalam pengadaan barang dan jasa, Unit Pengawasan Intern melakukan pengawasan dengan cara:

a. Melakukan pengawasan langsung terhadap kegiatan/proyek yang dilaksanakan

b. Melakukan pemeriksaan terhadap proses pelaksanaan pengadaan barang dan jasa sesuai tupoksinya

c. Menampung dan menindaklanjuti pengaduan masyarakat yang terkait dengan permaslahan/penyimpangan dalam pelaksanaan pengadaan barang dan jasa.

d. Menyampaikan laporan berkala insedentiil kepada pimpinan instansi yang bersangkutan.

4. Masyarakat 
Masyarakat merupakan muara terakhir atas seluruh pekerjaan pengadaan barang dan jasa, terkait dengan penyelenggaraan pemerintah yang berhubungan langsung dengan pelayanan kepada masyarakat. Agar penyelenggaraan pemerintahan dapat terlaksana dengan baik (good governance) dan bersih (clean governance) maka perlu adanya pengawasan dari penerima jasa pelayanan tersebut.

\section{PENUTUP}

\section{Kesimpulan}

Pengadaan barang dan jasa secara elektronik (e-procurement) adalah sistem yang tepat digunakan karena lebih transparan, efektif dan efisien jika dibandingkan dengan pengadaan barang dan jasa sistem konvensional (face to face). Aturan hukum perundangundangan yang mengatur tentang $e$ procurement dirasakan belum efektif karena pengaturannya masih belum spesifik, baik dalam hal substansi maupun teknis karena belum ada peraturan yang secara khusus mengatur tentang e-procurement. Perlu segera dibentuk undang-undang yang mengatur tentang pengadaan barang dan jasa secara elektronik (eprocurement) agar pelaksanaan $e$ procurement dapat lebih efektif. Dengan adanya undang-undang maka pengadaan barang dan jasa memiliki kekuatan hukum yang mengikat dan memiliki sanksi yang lebih tegas terhadap kasus pelanggaran yang mungkin terjadi. Sanksi yang ada sekarang terhadap pelaku yang melakukan kecurangan dalam proses pengadaan barang dan jasa masih ringan. Undang-undang yang dibuat nantinya diharapkan dapat memberikan sanksi yang lebih tegas dan lebih berat bagi pelaku yang melakukan penyimpangan dalam proses pengadaan barang dan jasa sehingga diharapkan dapat menimbulkan efek jera bagi pelakunya. Karena tujuan hukum dan perundang-undangan secara umum adalah menciptakan suatu masyarakat yang harmonis, tindakan-tindakan yang bersifat mengancam kelangsungan keharmonisan kehidupan masyarakat sebaiknya dibuang jauh dan dicegah.

\section{Saran}

Peranan lembaga pengawasan pengadaan barang dan jasa belum optimal karena masih ditemukan banyaknya penyelewengan terhadap proses pengadaan barang dan jasa. Dengan adanya sistem e-audit diharapkan proses pengawasan dapat lebih transparan.

\section{DAFTAR PUSTAKA}

Ali, Achmad., Menguak Teori Hukum (Legal Theory) dan Teori Peradilan (Judicialprudance) Termasuk Interpretasi UndangUndang (Legisprudance). Jakarta: Prenada Media Group, 2009.

Amiruddin. Korupsi Dalam Pengadaan Barang dan Jasa. Yogyakarta: Genta Publishing, 2010.

Ashshofa, Burhan. Metode Penelitian Hukum. Jakarta: Rineka Cipta, 2007.

Dimyati, Khudzaifah. Teorisasi Hukum: Studi Tentang Perkembangan Pemikiran Hukum di Indonesia 1945-1990. Surakarta: Muhammadiyah University Press, 2005.

Hakim, Abdul Aziz. Negara Hukum dan Demokrasi di Indonesia.Yogyakarta: Pustaka Pelajar,2011.

Halim, Abdul dkk. Pengelolaan Keuangan Negara-Daerah: 
Hukum, Kerugian Negara, dan Badan Pemeriksa Keuangan. Yogyakarta: UPP STIM YKPN, 2011.

Indriati, Maria Farida. Ilmu PerundangUndangan, Dasar-Dasar dan Pembentukannya. Jakarta: Kanisus, 1998.

Irianto, Sulistyowati dan Sidharta. Metode Penelitian Hukum Konstelasi dan Refleksi. Jakarta: Yayasan Pustaka Obor Indonesia, 2009.

Kamaroesid, Herry dkk. Pembuat Komitmen, Wewenang dan Tanggungjawabnya dalam Pelaksanaan APBN/APBD. Jakarta: Mitra Wacana Media, 2010.

Lubis, Andi Fahmi dkk. Hukum Persaingan Usaha Antara Teks dan Konteks. Jakarta: GTZ, 2009

Makarim, Edmon. Tanggung Jawab Penyelenggara Terhadap Tata Kelola yang Baik Dalam Penyelenggaraan Sistem Elektronik (Good Electronic Governence). Depok: Ringkasan Disertasi FHUI, 2009.

Mubaryanto dkk. Metode Penelitian Praktis. Yogyakarta: BP FE UGM,1987.

Nurachmad, Much. Buku Pintar Pengadaan Barang/ Jasa Pemerintah Berdasarkan PP Nomor 54 Tahun 2010 \& Peraturan Perundang-Undangan Terkait. Jakarta: Visimedia, 2011.

Saidi, Muhammad Djafar. Hukum Keuangan Negara. Jakarta: Rajagrafindo Persada, 2008.

Simamora, Y.Sogar. Hukum PerjanjianPrinsip Hukum Kontrak Pengadaan Barang dan Jasa oleh Pemerintah. Yogyakarta: LaksBang PRESSindo.2009.
Soekamto, Sarjono. Pengantar Penelitian Hukum. Jakarta: Universitas Indonesia Press, 2007.

Sutedi, Adrian. Aspek Hukum Pengadaan Barang dan Jasa dan Berbagai Permasalahannya. Jakarta: Sinar Grafika, 2010.

Witanto. Dimensi Kerugian Negara dalam Hubungan Kontraktual (Suatu Tinjauan Terhadap Risiko Kontrak Dalam Proyek Pengadaan Barang/Jasa Instansi Pemerintah). Bandung: CV Mandar Maju, 2012.

Zein, Ahmad Yahya. Kontrak Elektronik \& Penyelesaian Sengketa Bisnis ECommerce dalam Transaksi Nasional dan Internasional. Bandung: CV. Mandar Maju, 2009.

Republik Indonesia. Undang-Undang Nomor 31 Tahun 1999 tentang Pemberantasan Tindak Pidana Korupsi. Lembaran Berita Negara Nomor 3874 Tahun 1999.

Republik Indonesia. Undang-Undang Nomor 20 Tahun 2001 tentang Perubahan UU No.31 Tahun 1999 tentang Pemberantasan Tindak Pidana Korupsi. Lembaran Berita Negara Nomor 4150 Tahun 2001.

Republik Indonesia. Undang-Undang Nomor 17 Tahun 2003 tentang Keuangan Negara. Lembaran Berita Negara Nomor 4286 Tahun 2003.

Republik Indonesia. Undang-Undang Nomor 1 Tahun 2004 tentang Perbendaharaan Negara. Lembaran Berita Negara Nomor 5 Tahun 2004.

Republik Indonesia. Undang-Undang Nomor 15 Tahun 2004 Tentang Pemeriksaan Pengelolaan dan Tanggung Jawab Keuangan 
Negara. Lembaran Berita Negara Nomor 4400 Tahun 2004.

Republik Indonesia. Undang-Undang Nomor 11 Tahun 2008 tentang Informasi dan Transaksi Elektronik. Lembaran Berita Negara Nomor 4633 Tahun 2008.

Republik Indonesia. Undang-Undang Nomor 14 Tahun 2008 tentang Keterbukaan Informasi Publik. Lembaran Berita Negara Nomor 4846 Tahun 2008.

Republik Indonesia. Keputusan Presiden Nomor 80 Tahun 2003 sebagaimana diubah menjadi Peraturan Presiden Nomor 54 Tahun 2010 tentang Pengadaan Barang/Jasa Pemerintah.

LKPP. Peraturan Kepala Lembaga Kebijakan Pengadaan Barang/ Jasa Pemerintah Nomor 1 Tahun 2011 tentang Tata Cara E-Tendering.

LKPP. Peraturan Kepala Lembaga Kebijakan Pengadaan Barang/Jasa Pemerintah tentang Layanan Pengadaan Secara Elektronik.

DEPKOMINFO.http://www.depkominf o.go.id/produk/certificationauthority. Didwonload pada tanggal 16 April 2018.

Guntami, Ugun, Teori Keadilan Dalam Perspektif Hukum Nasional, 2011 dalamhttp:ugun.guntari.blogspot.c o.id/2011/12/teori-keadilandalam-perspektif-hukum.html di ases tanggal 27 januari 2018.

LKPP,

http://www.lkpp.go.id/v2/content .php?mid=8474545499 didownload pada tanggal 5 Mei 2018. http://www.blog.limc4u.com/2012/12/ penjelasan-pasal-1-uud1994.html.diakses tgl 13 Januari 2015,jam 12.30 WIB

https://hmibecak.wordpress.com.diaks es tgl 13 Januari 2015,jam 13.24 WIB

https://taufiqnugroho.blogspot.com.di akses tgl 13 Januari 2015,jam 13.45 WIB

Http://Adln.Lib.Unair.Ac.Id/. didownload pada tanggal 5 Mei 2018.

https://www.transparency.org/news/fea ture/corruption perceptions inde x 2018. diakses tgl 21 Mei 2018, jam 10.30 WIB

http://report-

lpse.lkpp.go.id/v2/public/index,. Diakses tgl 21 Mei 2018, jam 10.35 WIB

https://news.detik.com/berita/d3885311/icw-korupsi-pengadaanbarang-2017-meningkat-negararugi-rp-1-t. diakses tgl 21 Mei 2018, jam 12.00 WIB

http://forum.pengadaan.org/phpbb/vie wtopic.php? $\mathrm{f}=6 \& \mathrm{t}=480, \quad \mathrm{di}$ download tanggal 19 April 2012.

Hemat Dwi Nuryanto. Pentingnya Audit dan Standardisasi E-Procurement. Harian Pikiran Rakyat, Kamis 5 Maret 2009.

http://www.hukumonline.com/berita/b aca/lt5af1593ebc71b/sektorperizinan-masih-menjadi-lahanempuk-korupsi-pejabat-daerah. diakses tgl 21 Mei 2018, jam 12.40 WIB

http://kws.kpk.go.id/. Diakses tgl 21 Mei 2018, jam 12.40 WIB 